\title{
Suksesi Kepemimpinan Kraton Ngayogyakarta dalam Dualitas Struktur
}

\author{
Wahyuni Choiriyati \\ Dosen Fakultas Ilmu Komunikasi Universitas Gunadarma \\ Jalan Margonda Raya No. 100 Depok 16424, Jawa Barat, Indonesia. \\ Email: choiri@staff.gunadarma.ac.id
}

\begin{abstract}
King declaration was delivered by Sultan Hamengkubuwono Xexposing his princess for next in order to be crowned in Yogyakarta's palace.This raised contentious among Sultan Hamengkubuwono and his brothers. This was wrapped in cultural communication practicess in high level of context that was not easy to understand especially for society in general. This writing is to focus signifying king declaration in society in line to deep structure and culture. By phenomenology approach with critical paradigm, data gathered by in depth interviews and observation. Results of research found that king decralation was perceived as high context communication practices. This tended to economic political nuances. Nowdays, King has not dedicated to serve the society yet, but he tended to want to be respected. Power structure was maintained to secure the power legitimation including reveneu of land taxes and royal familiy businesses in palace. Each of them played the significant roles to secure and maintain in inner cirlce of power in the palace.
\end{abstract}

Keywords: succession of leadership, structure, power, culture and communication

\begin{abstract}
Abstrak
Sabdaraja yang disampaikan oleh Sultan Hamengkubuwono X mengungkapkan bahwa putri sulungnya akan diangkat menjadi penerus tahta kraton Yogyakarta. Hal ini menimbulkan ketegangan antara sultan Hamengkubuwono X dengan adik-adiknya. Semua ini dikemas dalam praktik komunikasi budaya konteks tinggi yang tidak mudah diterjemahkan masyarakat awam. Fokus tulisan ini adalah menggambarkan pemakanaan masyarakat Yogyakarta terkait sabdaraja dan segala hal yang berkaitan dengan struktur kekuasaan dan budaya yang melingkupinya. Menggunakan strategi fenomenologi dengan paradigma kritis, data digali dengan melakukan wawancara mendalam dan observasi pada enam orang yang dianggap memahami konteks permasalahan ini di Yogyakarta. Hasil penelitian menunjukkan bahwa praktik komunikasi keluarga kraton merupakan bagian dari budaya konteks tinggi yang agak sulit dimakanai orang awam. Posisi sebagai pemimpin memberikan keuntungan secara politik dan ekonomi sehingga menimbulkan kontestasi dan ketegangan. Hal ini nampak dalam bisnis keluarga keraton dan pajak tanah yang diterima. Hal ini akan terus dilanggengkan melalui struktur budaya yang ada. Pemimpin tidak lagi berusaha melayani saat ini melainkan cenderung dilayani. Masyarakat dianggap tidak memiliki kepekaan dan tatanan kritis sehingga menerima tafsir strukturasi kekuasaan dengan terbuka karena dogma seorang Raja. Hal ini merupakan kekuatan yang dimainkan aktor sosial dalam realitas budaya, karena masyarakat sejatinya menghendaki sebuah wacana yang terbuka, arif dan bijak mengikuti elemen rasionalitas sekaligus kesadaran atas peran pemimpin bagi rakyatnya.
\end{abstract}

Kata Kunci: Suksesi Kepemimpinan, Struktur, Kekuasaan, Budaya dan Komunikasi 


\section{Pendahuluan}

Bagi warga Yogyakarta yang mencermati Sabda Raja Sri Sultan HB X pada bulan April hingga Mei 2015 sempat mengalami kegelisahan, yang berujung pada kegaduhan opini warga terkait pada keputusan Sultan HB X. Masyarakat hanya dapat meraba-raba makna Sabdaraja yang dinilai dilingkupi misteri. Merujuk pada istilah Tajuk Rencana harian Kedaulatan Rakyat yang terbit pada 6 Mei 2015, Sabdaraja adalah titah raja dengan nilai lebih tinggi dari Sabdatama. Isi Sabdaraja tersebut pertama, penyebutan Buwono menjadi Bawono. Kedua, tidak lagi menggunakan gelar khalifatullah. Ketiga, Kaping Sedasa diganti menjadi Kaping Sepuluh. Keempat, akan mengubah perjanjian antara pendiri Mataram Ki Ageng Giring dengan Ki Ageng Pemanahan. Kelima, HB X akan menyempurnakan keris Kanjeng Kyai Ageng Kopek dengan Kanjeng Kyai Ageng Joko Piturun.

Bila disimpulkan, maka masyarakat Yogyakarta bisa memaknai Sabdaraja tersebut mengarah kemungkinan pada suksesi perempuan. Sehingga akan dimungkinkan dinobatkannya perempuan sebagai penerus raja. Bila dicermati, melalui pernyataan seorang Budayawan dan Sejarawan Yogya, M Jazir ASP yang termuat pada Harian Kedaulatan Rakyat 6 Mei 2015, menafsirkan bahwa Sabdaraja (yang dapat dibilang dekrit) ternyata membuat gejolak di kalangan internal Kraton Yogyakarta. Dari sudut pandang sejarah, Sabdaraja dinilai menyimpang dari paugeran atau konstitusi kraton.

Di era keterbukaan pers seperti saat ini, suatu peristiwa sulit tidak dilihat dan didengar masyarakat luas. Dengan tiadanya penjelas dan suatu penegasan resmi, masyarakat tidak bisa disalahkan mengalami sebuah heterofili komunikasi dalam penerimaan pesan. Terlebih bagi mereka yang merupakan warga Yogyakarta, nampak larut dalam melihat dan menilai kondisi kraton saat ini. Melalui serangkaian observasi, baik sekedar obrolan warung kopi di sudut kota Yogyakarta, hingga menjadi diskusi yang memanas di tingkat akademisi dan cerdik cendekia. Melalui sudut pandang ilmu masing-masing, masyarakat nampak mengikuti dengan seksama gejolak kraton. Kebanyakan mencemaskan "sesuatu" terkait dengan sinar keagungan Kraton Yogyakarta.

Dalam konteks komunikasi trans budaya, terdapat kondisi Heterofili, dimana budaya seseorang akan tercermin dalam praktik komunikasi dengan orang lain. Karena itu, komunikasi akan berlangsung damai apabila masing-masing komunikan memiliki pengertian yang mendalam tentang latar budaya masingmasing. Ada banyak hal yang dapat dipelajari diantaranya persepsi, serta bentuk-bentuk komunikasi baik verbal maupun nonverval dalam setiap peristiwa budaya.

Merujuk pada situasi ini, kondisi dan suasana di Kraton Yogyakarta, masyarakat dapat menangkap pesan budaya melalui media massa yang tidak luput memberitakan berbagai sepak terjang Sri Sultan HB X terkait Sabdaraja yang dikeluarkannya. Bagaimana resistensi yang diekspresikan oleh empat adik-adik Sultan dalam aksi atau laku spiritual dengan melakukan "sowan" atau mengadu dan memohon maaf atas kondisi Kraton Yogyakarta saat ini, kepada para leluhur dengan melakukan ziarah merupakan sebuah tindakan elegan. Langkah keempat bangsawan ini, mencerminkan kebijaksanaan dan kedalaman hati yang dapat menjadi teladan. Dalam berbagai diskusi yang mengemuka di masyarakat, sikap para adik Sultan ini dianggap santun, elegan dan mampu mengendalikan diri dari perasaan kecewa dan amarah.

Mengutip pada pernyataan Pengamat kebudayaan Universitas Indonesia, Karsono Kardjo Saputra pada Harian Tempo yang terbit 13 Mei 2015, menyatakan tak ada suksesi takhta kerajaan yang terjadi tanpa darah atau konflik dalam sejarah Asia Timur dan Tenggara. Sejumlah negara, termasuk Indonesia, memiliki catatan konflik panjang, bahkan pembunuhan, dalam penentuan calon pengganti penguasa. Hal tersebut berbeda dengan suksesi kerajaan di Eropa yang sudah diatur dalam undang-undang, sehingga suksesi relatif berjalan lancar.

Terkait topik riset dalam polemik internal 
Kraton Yogyakarta mengenai suksesi takhta Sri Sultan Hamengku Bawono X, Karsono Kardjo Saputro menilai bahwa peluang adik kandung Sultan menjadi pewaris takhta Kerajaan Mataram Islam, yang berdiri pada abad ke-17, itu pupus. Menurutnya, Sultan yang memiliki anak perempuan telah mengeluarkan Sabdaraja kedua pada 5 Mei 2015, yang isinya mengangkat anak sulungnya sebagai putri mahkota. Dalam sabda tersebut, Sultan mengubah nama putri pertamanya, Gusti Kanjeng Ratu Pembayun, menjadi GKR Mangkubumi Hamemayu Hayuning Bawono Langgeng Ing Mataram?. Pengubahan nama ini dianggap menjadi langkah Sultan mempersiapkan Pembayun sebagai putri mahkota Kesultanan Yogyakarta.

Berdasarkan data observasi dalam penelitian Sabdaraja dan polemik internal Kraton, peneliti melihat bahwa friksi dan konflik tidak semata soal jabatan raja, tapi juga posisi politik sebagai Gubernur Daerah Istimewa Yogyakarta. Seperti termuat dalam UndangUndang Keistimewaan Yogyakarta (UUK) No 13 tahun 2012, bahwa Raja yang memerintah Yogyakarta secara otomatis ditetapkan sebagai Gubernur Daerah Istimewa Yogyakarta. Selain itu, posisi sultan dapat dikategorikan potensial mengingat banyaknya aset yang dimiliki Kraton Yogyakarta. Melalui penelitian Fenomenologi Kritis, penelitian ini berusaha untuk membongkar naturalisasi struktur dalam suatu budaya yang berjalan secara pervasif (merembes) dalam balutan budaya konteks-tinggi.

Secara makro persoalan suksesi takhta di kerajaan manapun jarang terjadi tanpa darah atau konflik. Dalam sejarah Asia Timur dan Tenggara, sejumlah negara, termasuk Indonesia, memiliki catatan konflik panjang, bahkan pembunuhan, dalam penentuan calon pengganti penguasa. Sedangkan secara mikro (konteks Indonesia), Kraton Yogyakarta merupakan representasi realitas perebutan kekuasaan secara pervasif. Penanda suksesi telah nampak diskenariokan aktor-aktor yang terlibat dalam kepentingan kekuasaan. Munculnya persepsi demikian dibangun dengan asumsi terdapat ketidakwajaran dan ketidaksejajaran dalam relasi antara aktor yang merupakan priyayi atau bangsawan yang dari perspektif hirarki dan sejarah justru terabaikan dan teralienasi dalam struktur kekuasaan itu sendiri. Hal ini kemudian menciptakan sebuah pertanyaan mengenai bagaimana masyarakat Yogyakarta menafsirkan makna Sabdaraja sebagai struktur kekuasaan yang dilanggengkan dalam konteks Komunikasi Trans Budaya serta praksis dualitas struktur dalam suksesi kepemimpinan Kraton Yogyakarta.

Hal ini kemudian untuk menggambarkan kecenderungan berbagai peran peneguhan kekuasaan melalui serangkaian struktur-struktur budayayang dilegitimasimelaluiberbagaipranata sosial. Serta hal ini juga untuk menjelaskan indikasi-indikasi ideologi kapitalistik yang mendasari munculnya kecenderungan peran aktor dalam struktur budaya yang dominan yang dilakukan oleh aktor yang memiliki kekuasaan terstruktur dengan menggunakan studi fenomenologi dalam perspektif kritis.

\section{Metode Penelitian}

Di hampir wilayah nusantara ini kerajaan sebesar Kraton Yogyakarta merupakan kerajaan yang memiliki penguasa yang dinamis dalam kiprah budaya dan politik nasional di tanah air. Salah satu fenomena yang ditafsirkan secara politis oleh banyak pihak terjadi dalam beberapa bulan trakhir di lingkungan Kraton Yogyakarta. Dalam rentang waktu April hingga Mei 2015 terdapat peristiwa bersejarah yang menjadi catatan penting bagi masyarakat Yogyakarta. Salah satunya adalah Sabdatama dan Sabdaraja yang menyita perhatian masyarakat, akademisi, budayawan bahkan politisi nasional dalam mencermati Sabda tersebut. Pemilihan topik penelitian yang berkaitan dengan kekuasaan yang melekat pada struktur budaya ini memberikan konsekuensi metodologis dan konseptual pada penggunaan paradigma kritis (critical paradigm).

Asumsi yang mendasari penggunaan paradigma kritis ini disebabkan oleh tafsir pada penggunaan kekuasaan melalui lahirnya Sabda 
atau Dawuh Raja. Dimana distribusi kekuasaan terlihat tidak seimbang di masyarakat terhadap kaum priyayi yang notabene memiliki hak dan kesempatan yang sama sejalan dengan sejarah yang telah ada berabad-abad lamanya. Teori kritis, merujuk pada Littlejohn (2014) dicirikan oleh tiga hal, yaitu (1) terdapat upaya memahami pengalaman kehidupan masyarakat dalam konteks sosialnya; (2) terdapat upaya menemukan ketidakbenaran dalam suatu konstruksi sosial kemasyarakatan yang sudah melekat dalam keseharian masyarakat (3) terdapat sebuah upaya yang sadar untuk menyatukan antara teori dan tindakan.

Teori kritis dalam Littlejohn (1996), dibedakan dalam dua varian. Terbagi menjadi teori kritis strukturalis dan pasca-strukturalis. Kritis Strukturalis melihat bahwa strukturstruktur sosial yang menindas itu bersifat nyata, meskipun penindasan itu kadangkadang tersembunyi dan luput dari kesadaran kebanyakan orang. Lebih jauh, Littlejohn menguraikan bahwa struktur bersifat opresif dan menindas. Di lain pihak, varian kritis pascastrukturalis memandang tidak terdapat realitas atau makna sentral. Penindasan dalam struktur hanya berlangsung sementara. Apabila terdapat perjuangan menggugat struktur, maka yang muncul adalah perjuangan tunggal yang bersifat cair.

Dalam penelitian berbasis Komunikasi Trans Budaya, peneliti mencoba menempatkan perspektif teori kritis Strukturasi Giddens. Teori yang dipakai sebagai pisau analisis dalam penelitian ini diharapkan mampu membongkar penafsiran statis dan liniear yang mengemuka dalam wacana di masyarakat Yogyakarta terkait Sabdaraja. Sabdaraja sebagai bagian dari wacana simbolis dalam struktur budaya Kraton Yogyakarta mengenai aturan atau struktur yang dibangun atas nama kekuasaan sebuah kerajaan. Dari berbagai prinsip struktural, Giddens melihat tiga Gugus besar struktur. Pertama, struktur Signifikansi (signification) menyangkut skemata simbolis, penyebutan, dan wacana. Kedua, struktur dominasi (domination) yang mencakup penguasaan atas orang (politik) dan barang (ekonomi). Ketiga, struktur legitimasi menyangkut skemata peraturan normatif yang terungkap dalam tata hukum (Giddens dalam Wirawan, 2012).

Bila dikaitkan dengan konsep kekuasaan, dualitas struktur seperti terurai di atas dapat berfungsi sebagai alat analisis kehidupan sosial. Salah satunya adalah menjadi pisau analisis mengenai hubungan antara tindakan manusia dengan strukturnya. Berdasarkan hal tersebut, konsep Giddens yang diungkapkan oleh Wirawan (2012) memuat karakteristik utama dari kekuasaan menurut pandangan strukturasionis, antara lain:

1. Kekuasaan sebagai bagian integral dari interaksi sosial (power as integration to social interaction). Dalam setiap interaksi sosial selalu melibatkan kekuasaan, sehingga kekuasaan dapat diterapkan pada semua jenjang kehidupan sosial mulai dari yang sempit sampai dengan tataran yang lebih luas.

2. Kekuasaan adalah hal yang krusial dan pokok dalam diri manusia (power as intrinsic to human agency). Kekuasaan adalah kemampuan aktor untuk mempengaruhi dan mengintervensi serangkaian peristiwa, sehingga aktor dapat mengubah jalannya peristiwa tersebut.

3. Kekuasaan adalah konsep relasional, termasuk memuat hubungan otonomi dan ketergantungan (Power as relational concept, involving relations of autonomy and dependence). Dimaknai sebagai peran kekuasaan yang bukan sekedar kapasitas transformasi aktor mencapai tujuannya, melainkan juga konsep relasional. Ini berarti, setiap aktor dapat mempengaruhi lingkungan di mana peristiwa interaksi itu terjadi, agar aktor lain memenuhi keinginannya. 4. Kekuasaan selain bersifat membatasi juga memberi kebebasan (power as contraining as well as enabling). Dalam kehidupan seharihari kekuasaan bergandengan tangan dengan dominasi yang terstruktur. Anggota masyarakat tidak hanya mengintervensi jalannya inetraksi, tetapi juga mencoba melakukan kontrol perilaku orang lain. Ini dilakukan dengan sarana sanksi 
yang telah tersedia secara struktur.

5. Kekuasaan sebagai proses (power as process). Hubungan dialektik antara aktor dan struktur tidaklah bersifat statis, tetapi secara kontinu melakukan produksi dan reproduksi melalui proses yang disebut strukturasi.

Dari konsep pemikiran diatas, relasi Sabdaraja sekaligus actor-aktor yang terlibat penuh dalam sabda raja tersebut merupakan pengejawantahan dari konsep kekuasaan. Bagaimana aktor-aktor yang terlibat dalam interaksi secara terus-menerus dan rutin membangun, memelihara, mengubah dan mentransformasi hubungan-hubungan kekuasaan tersebut baik pada level mikro maupun makro. Mencakup dominasi dan subordinasi yang terlibat dalam proses interaksi oleh faktor-faktor untuk memelihara hubungan kekuasaan tadi.

Ketidakmampuan membaca pikiran dalam konteks budaya, menurut pendapat beberapa ahli sebagai hal yang umum. Gudykunst dan Kim (2014) menguraikan bahwa komunikasi merupakan cara yang ampuh untuk mengatasi ketidakpastian dalam menafsirkan budaya tersebut, dan simbol merupakan bagian terpenting dalam proses mengurai penafsiran budaya tertentu. Shimanoff (1987) menunjukkan bahwa komunikasi bersifat kontekstual karena komunikasi terjadi pada situasi atau sistem tertentu yang mempengaruhi bagaimana kita berkomunikasi dan arti dari pesan yang dibawa. Bagaimana pakaian Sultan HB X selaku raja Kraton Yogyakarta yang mengenakan kupluk (peci) berwarna biru, penetapan nama dan gelar baru dilakukan dengan duduk di Batu Gilap Siti Hinggil (Batu Gilap hanya boleh diduduki oleh calon pewaris tahta kerajaan). Pakaian bahkan bahasa berupa dhawuh (sabda) raja dalam konteks penelitian ini sejalan dengan pemikiran Shimanoff, bahwa simbol-simbol tersebut semuanya diadaptasikan dalam konteks.

Konteks budaya oleh Gudykunst dan Kim (2014) didefinisikan sebagai komponen terbesar yang meliputi ruang lingkup di mana komunikasi itu terjadi. Logika ini dilandasi bahwa dalam konteks komunikasi selalu melibatkan perilaku dan peraturan yang dipelajari dan dibawa dalam proses komunikasi. Konteks budaya sendiri terkait dengan konteks lingkungan, kesempatan, waktu, jumlah orang yang mengatur alur komunikasi. Konteks budaya terkait jumlah orang dalam sabdaraja dapat dimaknai dengan sikap para pangeran yang merupakan adik-adik raja dengan elegan tidak bersedia hadir dan justru melakukan counter hegemony terhadap sabda tersebut dengan laku prihatin menziarahi makam leluhur.

Dalam memaknai budaya konteks tinggi, arti dari informasi yang dipertukarkan selama interaksi tidak harus dikomunikasikan lewat kata-kata. Salah satu alasan bahwa arti kata kadangkala tidak harus dikatakan secara verbal dalam budaya konteks-tinggi adalah karena sifat masyarakat yang homogen. Mereka memiliki pengalaman dan informasi yang sama, dan protokol sosial yang tetap. Diasumsikan dalam budaya konteks-tinggi, tradisi dan sejarah hanya mengalami sedikit perubahan dalam kurun waktu tertentu. Hofstede dalam Samovar (2014) menekankan bahwa budaya konteks tinggi lebih sering ditemukan dalam budaya tradisional. Salah satu penyebabnya adalah budaya yang memuat suatu pesan yang konsisten menghasilkan respon yang konsisten pula dalam lingkungan sosial. Karena arti tidak selalu terdapat dalam katakata. Dalam budaya konteks tinggi, informasi disediakan melalui kesimpulan, gerakan, dan bahkan dalam suatu keheningan.

Masyarakat dalam budaya konteks-tinggi cenderung waspada terhadap lingkungan sekitar mereka dan dapat menyatakan serta mengartikan perasaan tanpa menyatakannya secara verbal. Andersen (1978) dalam bukunya Myth to Live tahun 1978, mengungkapkan "budaya konteks-tinggi percaya pada komunikasi nonverbal". Arti dalam budaya konteks-tinggi juga dinyatakan "melalui status (usia, jenis kelamin, pendidikan, latar belakang keluarga, gelar dan afiliasi). Senada dengan yang diungkapkan Gudykunst (dalam Samovar, 2014),"pesan" komunikasi yang digunakan oleh budaya konteks-tinggi dilakukan dengan cara tidak 
langsung, masyarakat yang menganut budaya ini bergantung pada bagaimana sesuatu itu dikatakan, lebih daripada apa yang dikatakan, dan waspada terhadap isyarat non verbal.

Mengutip ungkapan Clifford Geerzt dalam Bukunya berjudul Agama Jawa (2013), kalangan priyayi memiliki etika dengan kepekaannya yang tinggi terhadap perbedaan status. Para Priyayi diceritakan oleh Geerzt memiliki tingkat bahasa yang lebih tinggi bila diucapkan dengan benar. Mereka juga memiliki semacam kemegahan kenegaraan yang bisa membuat percakapan paling sederhana tampak sebagaimana upacara besar. Dalam kasus Sabdaraja ini, nampak untaian sabda yang tidak mudah dieterjemahkan masyarakat di luar kraton Yogyakarta.

Pernyataan Geerzt ini diametral dengan Hipotesis Sapir-Whorf (dalam Mulyana, 2008) yang menyatakan bahwa ketika orang belajar bahasa suatu budaya atau sub budaya tertentu, maka perhatiannya diarahkan kepada aspekaspek realitas atau hubungan yang penting dalam konteks tersebut. Sapir-Whorfmenyatakan bahwa bahasa memuat dua hal penting. Pertama, berlaku sebagai alat bantu memori. Bahasa membuat memori lebih efisien bila kita menyandi peristiwa sebagai kategori verbal. Situasi ini terlihat nyata dalam Sabdaraja yang terkesan berlaku bagi kalangan internal kraton, namun ditafsirkan secara meluas oleh masyarakat dengan penanda bahwa suksesi Kraton Yogyakarta sudah dimulai dengan penanda lahirnya raja perempuan yang mengubah suksesi kerajaan Mataram selama beraba-abad. Kedua, bahasa memungkinkan individu untuk mengabstraksikan apa saja yang berasal dari pengalaman. Hal ini terutama penting dalam mengungkapkan suatu hubungan abstrak. Representasi asusmi kedua Sapir-Whorf dapat dilihat dalam istilah sabdaraja atau dawuh raja menurutSultan HB X dalampenjelasannya seperti dimuat oleh Nova edisi 1420/XXVIII yang terbit 11-17 Mei 2015. Sabdaraja merupakan Perintah Allah SWT yang kemudian diterjemahkan Sultan melalui Sabdaraja dan Dawuhraja kepada orang lain dan keluarganya secara tertutup di kraton.
Sabdaraja dibacakan secara utuh dalam bahasa Jawa. Poinnya adalah, bahwa Sultan merasa Allah SWT telah memerintahkan dirinya melalui para leluhurnya. Perintah Allah SWT lewat para leluhurnya itu dikatakan Sultan amat mendadak. "Jadi harus dilaksanakan tidak boleh menggerutu. Kalau tidak dilaksanakan akan tergulung oleh zaman" demikian mengutip penyataan Sultan HB X dalam liputan Nova. Sultan merasa takut bila tidak melaksanakan perintah itu akan kena laknat Allah SWT. Bahkan disampaikan Sultan karena mendadak harus dilaksanakan, bahkan Ratu Hemas selaku istri Sultan harus bangun jam lima langsung berhias.

Ada tiga elemen utama dalam Fenomenologi Dunia Sosial Alfred Schutz, yaitu dunia kehidupan sehari-hari, sosialitas serta makna dan pembentukan makna. Pertama, dunia kehidupan sehari-hari adalah dunia yang paling fundamental dan terpenting dalam kehidupan manusia. Dalam dunia kehidupan sehari-hari terbentuklah makna, bahasa dan interaksi sosial yang membentuk perilaku bersama yang kemudian diterima bersama oleh anggota masyarakat. Dunia kehidupan sehari-hari merupakan kenyataan dasar sehingga kenyataan sosial dapat dipahami. Dunia kehidupan seharihari merupakan suatu realitas terpenting dalam kehidupan manusia (Sobur, 2013).

Kedua, sosialitas dikembangkan dari Teori Tindakan Sosial Max Weber dimana tindakan sosial merupakan perbuatan yang diarahkan kepada orang lain. Sosialitas atau kesosialan merupakan kenyataan bahwa manusia tumbuh dan berkembang dalam ranah interpersonal dimana kehidupan bersama menciptakan banyak cara dalam berpikir, menilai, merasa, berbicara dan berbuat agar kehidupan bersama mencapai taraf insani.

Ketiga, makna dan pembentukan makna berkaitan dengan penjelasan orisinal dari Schutz terkait gagasan Fenomenologi. Schutz menganggap gagasan Fenomenologi memberikan penjelasan bagaimana makna membentuk struktur sosial. Makna dasar bagi pengertian manusia adalah akal sehat. Akal sehat 
adalah pengetahuan yang ada dalam setiap diri orang dewasa yang tidak hanya berasal dari pengalaman personal namun juga diturunkan secara sosial dari orang sebelumnya (Sobur, 2013).

untuk mengadakan penafsiran terhadap hubungan manusia dan masyarakatnya memiliki fungsi untuk mengadakan penjelasan terminologi bidang budaya. Strategi interpretive practice, adalah strategi yang dapat mengungkap kebenaran sebagaimana yang dimaksud. Hal ini diartikan, bahwa peneliti tidak bisa langsung ke lapangan tanpa pengetahuan atau pemikiran yang kosong. Namun justru melalui proses pengenalan metode atau pemahaman yang dilakukan dengan studi referensi yang komprehensif.

Informan dalam penelitian ini diambil melalui teknik Convenience Sampling, yang dianggap paling sederhana dan paling longgar dalam penelitian komunikasi kualitatif. Peneliti sekadar mengambil siapa saja untuk dijadikan wakil dari subyek penelitian dan kemudian mengamati atau memawawancarainya. Untuk mendapatkan kedalaman pada penelitian ini, warga yang merupakan masyarakat Yogyakarta juga dimintai informasi terkait Sabdaraja yang dikeluarkan Sultan HB X. Penelitian ini melibatkan 3 orang abdi dalem keraton, dan 3 orang warga Yogyakarta yang mengikuti perkembangan dan informasi seputar Sabdaraja Sultan HB X.

\section{Hasil dan Pembahasan}

Mekanisme pengisian jabatan dan tata kelola Kraton sudah selayaknya mulai dibuka. Hal ini merupakan bagian dari sebuah riset pendahulu yang merespon Sabdaraja Sultan HB X. Sabdaraja menuai polemik di Kraton Yogyakarta dan menyita perhatian warga Yogyakarta. Mengapa situasi ini dianggap penting bagi publik DIY? Hal ini penting supaya tidak menimbulkan kebingungan di kalangan masyarakat. Salah satunya diperkuat dengan hasil penelitian yang dilakukan oleh Jurusan Ilmu Pemerintahan Universitas Muhammadiyah
Yogyakarta, tahun 2015. Survey meminta pendapat tentang calon penganti Sultan HB X, sebanyak 30,2 persen menyatakan setuju dengan GKR Mangkubumi, 35,9 persen persen setuju jika penganti Sultan HB X adalah adiknya dan 33,9 persen responden menyatakan ragu-ragu. Data tersebut secara tidak langsung menggambarkan bahwa dukungan kepada perempuan Sultan HB $\mathrm{X}$ berbanding dukungan kerabat $\mathrm{HB} \mathrm{X}$ sebagai Sultan berikutnya relatif sama.

Saat dilakukan penelitian tentang dukungan (keterbukaan) terhadap pemimpin perempuan, angka paling tinggi ada di Sleman dengan persentase 41,7 persen, sedang yang terendah ada di Gunungkidul. Terungkap bahwa masyarakat DIY masih konsisten terhadap keistimewaan DIY mendukung posisi Sultan sebagai Raja Kraton sekaligus Gubernur. Untuk itu suksesi kepemimpinan Kasultanan Yogyakarta tidak bisa lagi hanya dilihat sebagai suksesi internal, tapi menjadi suksesi kepemimpinan kepala daerah. Namun sampai saat ini warga DIY belum mengetahui siapa yang akan menjadi Sultan pasca HB X. Karena itu, suksesi kepemimpinan Kraton Yogyakarta tidak bisa lagi hanya dilihat sebagai suksesi internal, tapi menjadi suksesi kepemimpinan kepala daerah (Gubernur DIY)

\section{Strukturasi dalam Budaya dan Politik Kekuasaan}

Tafsir mengenai kekuasaan yang pervasif dalam strukturasi Giddens dapat kita kaji dengan jelas adalam struktur budaya Kraton Yogyakarta. Melalui berbagai sumber dan fakta di lapangan, dapat kita ketahui bahwa Kekuasaan sebagai bagian integral dari interaksi sosial (power as integration to social interaction). Dalam setiap interaksi sosial selalu melibatkan kekuasaan, sehingga kekuasaan dapat diterapkan pada semua jenjang kehidupan sosial mulai dari yang sempit sampai dengan tataran yang lebih luas.

Seiring jatuhnya Orde Baru, kekuatan feodal kesultanan yang tersisa di Indonesia mengalami krisis. Krisis kekuasaan feodal dan kesultanan di Indonesia yang dihadapi oleh 
Yogyakarta adalah krisis legitimasi dan krisis ekonomi. Krisis yang pertama disebabkan oleh UU No 3 Tahun 1950 yang menyatakan bahwa ahli waris (keturunan) sultan akan selalu menjadi gubernur provinsi tanpa pemilu yang tidak sesuai dengan amandemen UUD 1945. Untuk mengatasi krisis tersebut, maka kesultanan mencoba untuk menata kembali (reorganizing atau reorganisasi) kekuatan melalui reorganisasi politik dan ekonomi. Reorganisasi kekuatan ekonomi dilakukan melalui rekonsentrasi Tanah Sultan dan Tanah Pakualam serta menghidupkan kembali bisnis lama dan juga komodifikasi aset dan properti kesultanan. Keraton beradaptasi dengan kondisi-kondisi baru seperti desentralisasi serta mereorganisasi kekuasaannya yang ditandai dengan munculnya kekuatan-kekuatan warisan Orde Baru pada tingkat lokal di era reformasi termasuk di Keraton Yogyakarta (Yanuardi, 2012).

Dalam tataran pengejawantahan kekuasaan, Giddens menguraikan bahwa Kekuasaan adalah konsep relasional, termasuk memuat hubungan otonomi dan ketergantungan (Power as relational concept, involving relations of autonomy and dependence). Dimaknai sebagai peran kekuasaan yang bukan sekedar kapasitas transformasi aktor mencapai tujuannya, melainkan juga konsep relasional. Ini berarti, setiap aktor dapat mempengaruhi lingkungan di mana peristiwa interaksi itu terjadi, agar aktor lain memenuhi keinginannya. Analisis kekuasaan dalam kepemilikan tanah juga jelas terlihat pada kepentingan Kraton. Tanah yang dimiliki Keraton ini disebut Sultaanat Ground (SG) dan Pakualamanaat Ground (PAG). Sebagaimana dicatat oleh Anderson dan Case dalam Dian Yunardi (2011), peran kekuasaan lokal yang memiliki akses dan kontrol atas tanah, adalah penting dalam menentukan arah perubahan agraria dan bagaimana tanah dijadikan untuk akumulasi kekayaan sehingga dapat diubah menjadi bidang lain seperti sebagai kekuatan politik dan kekuatan budaya.

Luas tanah yang dikuasai ini sangat besar dengan membentang di seluruh Propinsi
Yogyakarta. Data luas SG dan PAG yang dikeluarkan oleh Pemerintahan Propinsi Yogyakarta pada tahun 2005 lebih dari 6000 Ha. Sedangkan dalam data lainnya yang dirilis Himmah, lebih kecil dari itu yaitu $3778 \mathrm{Ha}$. Tanah SG kini terkonsentrasi di Yogyakarta, Bantul dan Sleman. Sedangkan, PAG banyak di Kulon Progo. Jumlah tanah tersebut, seperti telah dijelaskan sebelumnya, merupakan kepemilikan yang dimiliki turun temurun dari perjanjian Giyanti tahun 1755. Bentangan SG dan PAG di DIY bisa sedemikian luas sebab berdasarkan Rijksblad Kasultanan No. 16/1918 dan Rijksblad Kadipaten No. 18/1918, semua tanah yang tidak dapat dibuktikan merupakan hak eigendom (hak milik) orang lain, otomatis menjadi milik kesultanan dan kadipaten (Aditjondro, 2011)

Setelah rekonsentrasi dilakukan, ribuan hektar Tanah Sultan di seluruh Kraton kini terkonsentrasi di Yogyakarta, Bantul dan Sleman sedang Tanah Paku Alaman terkonsentrasi di Kulon Progo. Kedua jenis tanah keraton itu merupakan sumber pendapatan kraton dari sahamnya di Hotel Ambarukmo, Ambarukmo Plaza, Saphier Square, dan Padang Golf Merapi. Keraton jelas memainkan peran tidak hanya sebagai pemimpin politik melainkan melalui kekuasaan politiknya telah memainkan peran besar sebagai aktor ekonomi di Yogyakarta. Hal tersebut terlihat dengan jelas dimana sebagian besar anggota keluarga Sultan Hamengku Buwono X dan Paku Alam IX terjun dalam bisnis. Contoh lainnya misal pada tahun 2004, Sultan Hamengkubuwono X membangun sebuah pusat perbelanjaan besar dengan menghapus sebuah sekolah dasar dan situs budaya serta meningkatkan beragam bentuk proyek bisnis termasuk proyek pertambangan. Salah satu bisnis penting keluarga keraton Yogyakarta adalah perusahaan tambang pasir besi PT Jogya Magasa Mining (JMM) di Kulonprogo (Aditjondro, 2011).

Di lain pihak struktur dalam Giddens juga menyoroti Kekuasaan adalah hal yang krusial dan pokok dalam diri manusia (power as intrinsic to human agency). Kekuasaan adalah 
kemampuan aktor untuk mempengaruhi dan mengintervensi serangkaian peristiwa, sehingga aktor dapat mengubah jalannya peristiwa tersebut. Dalam kasus UUK Yogyakarta, aktoraktor sosial mengedepankan aturan-aturan yang melanggengkan kekuasaan melalui struktur regulasi. Praksis dalam penguatan kekuasaan dan struktur regulasi ini dapat terbaca melalui penerbitan Undang-Undang Keistimewaan Yogyakarta(UU Keistimewaan Yogyakarta) yang salah satu poin penting di dalamnya mengatur hak politik untuk menunjuk keturunan Kesultanan sebagai satu-satunya gubernur di Yogyakarta tanpa adanya pemilihan kepala daerah dan juga untuk menyelesaikan tuntutan hukum terhadap tanah Kesultanan. Legalisasi Tanah Kesultanan diatur melalui UU Keistimewaan Yogyakarta yang sudah berkali-kali ditekankan oleh Sultan Hamengkubuwono.

Persetujuan Legislatif atas UndangUndang Keistimewaan Yogyakarta (UU Keistimewaan Yogyakarta) telah memberikan hak secara legal bagi kesultanan untuk mengklaim dan mencabut hak milik tanah misalnya seperti yang telah terjadi di tanah pesisir yang telah dikelola oleh petani selama bertahun-tahun di Kulon Progo. Kesultanan mengklaim hak milik atas tanah yang dikelola petani tersebut. Padahal, sebelumnya tidak ada tanda-tanda keberatan atau adanya kepentingan dari kesultanan sebelum munculnya proyek penambangan pasir besi yang melibatkan investor asing. Sama seperti era-era sebelumnya, pada era reformasi pun tercipta suatu pemerintahan yang menyalahgunakan kekuasaannya untuk mendapatkan keuntungan pribadi yang sebesarbesarnya dengan mengabaikan kepentingan rakyat yang sesungguhnya. Lebih jauh, melalui paparan di atas dapat dilihat secara keseluruhan bahwa secara historis kekuatan ekonomi yang dimiliki oleh keraton pada era reformasi bukan merupakan hal yang baru melainkan merupakan sebuah sejarah yang panjang. Hanya saja dinamika politik dalam negeri telah mentransformasi bentuk dari kekuatan ekonomi tersebut melalui penguatan penguatan struktur budaya yang terus menerus dilanggengkan melalui kekuasaan.

\section{Kekuasaan: Membatasi juga Memberi Kebebasan}

Dalam kehidupan sehari-hari kekuasaan bergandengan tangan dengan dominasi yang terstruktur. Anggota masyarakat tidak hanya mengintervensi jalannya inetraksi, tetapi juga mencoba melakukan kontrol perilaku orang lain. Ini dilakukan dengan sarana sanksi yang telah tersedia secara struktural. Kekuasaan sebagai proses (power as process). Hubungan dialektik antara aktor dan struktur tidaklah bersifat statis, tetapi secara kontinu melakukan produksi dan reproduksi melalui proses yang disebut strukturasi.

Naturalisasi atas struktur yang opresif dari penguasa, memunculkan kritik mengenai longgarnya kebijakan Gubernur selaku Sultan HB X sekaligus penguasa Kraton Yogyakarta. Kritik terkait maraknya perijinan hotel berbintang di wilayah Yogyakarta. Berdasarkan data Badan Pusat Statistik (BPS) Daerah Istimewa Yogyakarta, sampai awal 2014 ada 399 hotel di Yogyakarta, terdiri dari 43 hotel bintang dan 356 hotel nonbintang. Adapun selama 2014, Dinas Perizinan Kota Yogyakarta telah mengeluarkan 67 izin mendirikan bangunan hotel baru sehingga jumlah hotel di Yogyakarta akan terus bertambah. Dampak sosial lain adalah lemahnya kekuatan politik seorang Sultan sekaligus Gubernur yang harus mampu mendekatkan pada kepentingan hajat hidup warga Yogyakarta. Saat ini Kota Yogyakarta menggelar acara Grebeg Mall Jogja 2013 sebagai salah satu bagian dari peringatan Hari Ulang Tahun Kota Yogyakarta ke-257. Hal ini memperkuat opini bahwa Penguasa Yogyakarta tidak mendukung perkembangan pasar tradisional dibandingkan dengan pasar modern. Selain mall, kota Yogyakarta juga sangat terbuka bagi jejaring minimarket yang telah sangat mempengaruhi tingkat penjualan pedagang di pasar tradisional. Pada rentang tahun 2007 - 2009, pertumbuhan toko modern di Yogyakarta mencapai 52\%, sedangkan pasar 
tradisional tidak tumbuh (stagnan). Pemerintah Kota Yogyakarta sebenarnya telah memiliki aturan pembatasan pertumbuhan toko moden maksimal 52 unit. Letaknya pun diharuskan berjarak minimal 400 meter dari pasar tradisional.

Suksesi kekuasaan dalam keraton Yogyakarta menjadi suatu hal yang menarik perhatian tidak hanya masyarakat Yogyakarta secara khusus namun juga masyarakat di Indonesia pada umumnya. Selama berabadabad, keraton Yogyakarta dipimpin oleh seorang laki-laki namun sepertinya hal ini akan berubah tidak lama lagi. Sultan Hamengkubuwono X yang tidak memiliki anak laki-laki sepertinya akan mewariskan tahta kesultanan Yogyakarta pada anak perempuan tertuanya. Hal ini sebetulnya sudah menunjukkan gejala sejak lama sebelum sabdaraja yang dikeluarkan Sultan Hamengkubuwono X dipublikasikan. Dalam sabdaraja tersebut, Sultan Hamengkubowono $\mathrm{X}$ secara implisit menjadikan anak sulungnya sebagai putri mahkota. Hal ini kemudian menciptakan sebuah polemic di dalam keluarga keraton.

Empat adik laki-laki sultan menolak keputusan Sultan Hamengkubuwono X untuk mengangkat putri tertuanya sebagai penerus tahta keraton Yogyakarta. Alih-alih menggunakan cara yang cenderung bersifat represif, ketidaksetujuan keempat adik sultan ditunjukkan dengan cara menziarahi makan para leluhur yang menyimbolkan bahwa mereka mengadu terkait langkah sultan Hamengkubuwono X yang mereka nilai melanggar aturan yang telah dijalankan sejak lama di Kraton Yogyakarta. Selain itu, posisi sebagai pemimpin kraton Yogyakarta memiliki manfaat tidak hanya dari segi politik namun juga dari segi material. Tidak heran suksesi kekuasaan ini menimbulkan ketegangan antara sultan Hamengkubowono X dengan adik-adiknya.

Praktik komunikasi yang nampak terkait suksesi kepemimpinan Kraton Yogyakarta ini adalah komunikasi dalam budaya konteks tinggi. Komunikasi dalam budaya konteks tinggi agak sulit dimaknai oleh orang awam. Hal ini terlihat tindakan protes yang dilakukan adik sultan Hamengkubuwono $\mathrm{X}$ atas keputusannya mengangkat putri sulungnya sebagai putri mahkota dengan menziarahi makam leluhur. Hal ini sebagai bentuk upaya menyampaikan pesan bahwa apa yang dilakukan oleh Sultan Hamengkubuwono $\mathrm{X}$ telah merusak aturan yang telah ditetapkan oleh leluhur mereka sekaligus mengungkapkan ketidaksetujuan mereka atas apa yang diputuskan oleh Sultan Hamengkubuwono X. Sultan Hamengkubuwono $\mathrm{X}$ juga menyampaikan pesan kepada publik jogja bahwasanya apa yang ia lakukan merupakan perintah dari Allah SWT yang disampaikan melalui para leluhur. Hal ini juga merupakan bagian dari bentuk komunikasi dalam budaya konteks tinggi.

Posisi sebagai pemimpin kraton Yogyakarta memberikan keuntungan paling tidak dari segi politik dan material. Dari segi politik, pemimpin kraton merupakan gubernur Daerah Istimewa Yogyakarta. Hal ini mengimplikasikan bahwa pemimpin kraton memiliki kekuasaan secara politik terhadap seluruh wilayah dan rakyat Daerah Istimewa Yogyakarta. Dari segi material, tanah yang ada di sejumlah wilayah di Yogyakarta merupakan tanah milik kraton. Artinya pajak yang dibayarkan oleh para penyewa baik itu yang bersifat lokal dari luar wilayah Yogyakarta memberikan pemasukan yang luar biasa kepada kraton. Keuntungan secara politik dan material ini tentunya akan saling berkaitan satu sama lain misalnya melalui berbagai kebijakan yang dikeluarkan untuk melanggengkan kekuasaan dan praktik akumulasi capital. Kondisi ini kemudian menyiratkan bahwa posisi sebagai penguasa sepertinya tidak lagi dimaknai sebagai pelayan rakyat melainkan posisi hebat yang menjanjikan keuntungan dan justru akan sering dilayani.

\section{Simpulan}

Kekuasaan yang dinaturalisasi dalam struktur budaya secara pervasif cenderung tidak disadari oleh masyarakat. Salah satunya apabila kekuasaan yang bersifat opresif dibalut dalam 
sebuah budaya konteks-tinggi yang hanya bisa dipahami oleh kelompok priyayi dan intelektual. Masyarakat dianggap tidak memiliki kepekaan dan tatanan kritis sehingga menerima tafsir strukturasi kekuasaan dengan terbuka karena dogma seorang Raja.

Aspek bahasa menjadi sangat penting, karena struktur yang berkuasa dalam budaya konteks-tinggi cenderung menggunakan ungkapan-ungkapan priyayi yang tidak mudah dan sengaja dibuat multifasir. Tentunya ini merupakan kekuatan yang dimainkan aktor sosial dalam realitas budaya, karena masyarakat sejatinya menghendaki sebuah wacana yang terbuka, arif dan bijak mengikuti elemen rasionalitas sekaligus kesadaran atas peran pemimpin bagi rakyatnya.

\section{Daftar Pustaka}

Denzin, Norman, K. \& Yvonna S.Lincoln (Ed.) 1994. Handbooks of Qualitative Research. London: Sage Publication

Geertz, Clifford. 2013. Agama Jawa: Abangan, Santri Priyayi Dalam Kebudayaan Jawa, Editor: Aswab Mahasin dan Bur Rasuanto. Depok: Pustaka Jaya Kuswarno, Engkus. 2009. Fenomenologi: Metode Penelitian Komunikasi. Bandung: Widya Padjadjaran Littlejohn, Stephen W dan Foss, Karen A. 2014. Teori Komunikasi, Edisi Sembilan. Salemba Humanika: Jakarta Littlejohn Stephen, W. 1996. Theories of Human Communication.(FifthEdition).Belmont: Wadsworth Publishing Company Mulyana, Deddy. 2001. Mengapa dan Untuk Apa Kita Mempelajari Komunikasi Antar Budaya, Dalam: Komunikasi Antar Budaya, Panduan Berkomunikasi Dengan Orang-Orang Berbeda Budaya, Editor: Deddy Mulyana dan Jalaluddin Rakhmat. Bandung: Remaja Rosdakarya. Mulyana, Deddy. 2003. Ilmu Komunikasi, Suatu Pengantar, cetakan kelima. Bandung: Remaja Rosdakarya.
Miles, M. B dan A. M Huberman . 1984. Analisis Data Kualitatif. Terjemahan oleh Tjetjep Rohendi. 1992. Jakarta: UI Press. West, Richard dan Turner, L.H. 2000. Introducing Communication Theory: Analysis and Application, Mountain View. CA: Mayfield PublishingRitzer, George, 1996, Modern Sociological Theory. The McGraw-Hill Companies: Singapore S.Shimanoff. 1980. Communication Rules: Theory and Research, Beverly Hills. CA: Sage Publication

Samovar, Larry A., Porter Richard E., dan McDaniel Edwin R. 2014. Komunikasi Lintas Budaya, Edisi 7, Jakarta: Salemba Humanika Sindhunata. 1978. Dilema Usaha Manusia Rasional. Gramedia: Jakarta Sunarto.2000. Analisis Wacana Ideologi Gender Media Anak-Anak. Semarang: Mimbar \& Yayasan Adikarya Ikapi serta Ford Foundation

Sobur, Alex. 2013. Filsafat Komunikasi Tradisi dan Metode Fenomenologi. Bandung: Rosda Karya Tubbs, Stewart L., dan Moss, Sylvia. 2008. Human Communication: PrinsipPrinsip Dasar, Editor Deddy Mulyana. Bandung : Remaja Rosdakarya Wirawan, IB. 2012. Teori-TeoriSosial Dalam Tiga Paradigma; Fakta Sosial, Definisi Sosial dan Perilaku Sosial. Kencana: Jakarta

\section{Makalah:}

Yanuardi, Dian , Commoning, Dispossession Projects and Resistance: A Land Dispossession Project for Sand Iron Mining in Yogyakarta, Indonesia, hlm 17. Disampaikan dalam International Conference on Global Land Grabbing II pada 17-19 Oktober 2012. (Organized by the Land Deals Politics Initiative (LDPI) and hosted by the Department of Development Sociology at Cornell University, Ithaca, NY). 


\section{Sumber Online:}

Aditjondro, George Junus. $S G$ dan $P A G$, Penumpang Gelap RUUK Yogyakarta. Harian sore Sinar Harapan, 31 Januari 2011. Diakses melalui http://indoprogress.com/2011/02/sgdan-pag-penumpang-gelap-ruuk-yogyakarta/ pada 2 Desember pukul 21.36 WIB. www.yogyakarta.bps.go.id, diakses 9 Desember 2015, pukul 14.10 WIB Surat Kabar dan Tabloid: Harian Kedaulatan Rakyat, terbit Yogyakarta, 4-5-6 Mei 2015

Tabloid Nova edisi 1420/XXVIII terbit 11-17 Mei 2015 